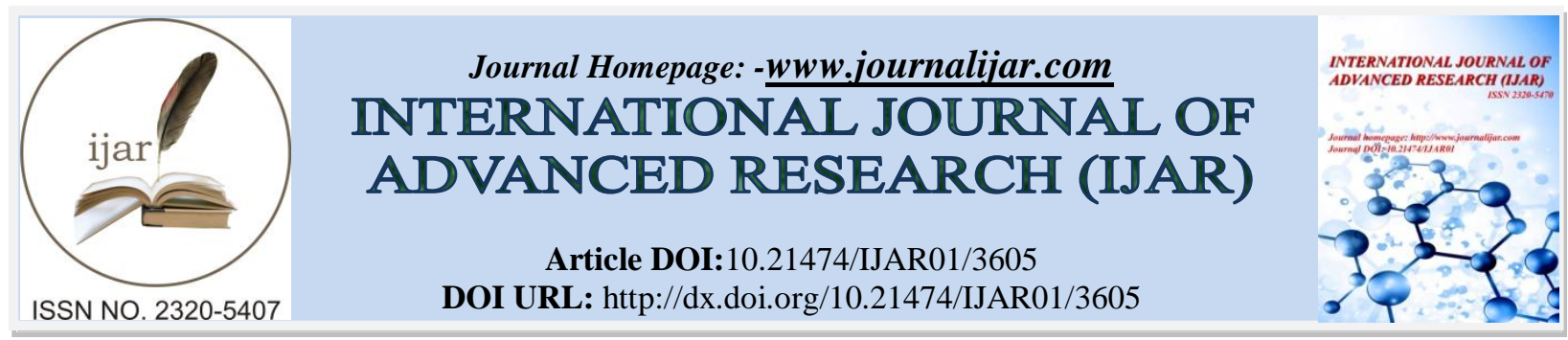

RESEARCH ARTICLE

\title{
PHYTOCHEMICAL SCREENING, ACUTE TOXICITY AND CARDIOVASCULAR EFFECTS OF WATER EXTRACT OF HALLEA LEDERMANNII (K. KRAUSE) VERDC (RUBIACEAE), MEDICINAL PLANT FROM GABON.
}

\section{Mba Akue Rony ${ }^{1,2 *}$, Bikanga Raphael ${ }^{1}$, Etou Ossibi Arnaud Wilfrid ${ }^{2}$, Nkounkou Loumpangou Celestine ${ }^{2}$ and Ouamba Jean-Maurille ${ }^{2}$.}

1. Laboratory of Naturel Substances and Organometallic Synthesis, University of Sciences and Technology of Masuku, BP 943, Franceville-Gabon.

2. Chemistry Unit of Plant and Life, Faculty of Science and Technology, University Marien Ngouabi, BP 69, Brazzaville-Congo.

\section{Manuscript Info}

Manuscript History

Received: 06 January 2017

Final Accepted: 05 February 2017

Published: March 2017

Key words:-

Phytochemical screening, acute toxicity,

Hallea ledermannii, secondary

metabolites, cardiovascular effects.

\begin{abstract}
Hallea ledermannii is a medicinal plant commonly used in traditional Gabonese medicine to fight against high blood pressure. The objective of this study was to determine the chemical profile and evaluate the acute toxicity and effect of the aqueous extract of Hallea ledermannii on cardiovascular parameters in normotensive rats. Phytochemical screening was carried out by using the usual methods of Bouquet. Acute oral toxicity was evaluated in mice at doses of 50, 300, 2000 and $5000 \mathrm{mg} / \mathrm{kg}$ in accordance with OECD Guideline 423. Tests on blood pressure and heart rate were realized by the invasive method in normotensive rats anesthetized at urethane $15 \%$. The results show that Hallea ledermannii contains many secondary metabolites. Its polar extracts have of the low contents in total phenol $(3.55675 \pm 0.083$, $3.27425 \pm 0.101,2.78675 \pm 0.110 \mathrm{mg} \mathrm{GAE} / \mathrm{g}$ of drugs) and total flavonoids $(1.2272 \pm 0.197 ; 0.7232 \pm 0.187 ; 0.8072 \pm 0.129 \mathrm{mg} \mathrm{QE} / \mathrm{g}$ of drugs). Aqueous extract of Hallea ledermannii is not toxic up to the $5000 \mathrm{mg} / \mathrm{kg}$ dose. This extract $(10,20$ and $30 \mathrm{mg} / \mathrm{kg}$ ) causes a low in systolic blood pressure and heart rate. These results suggest that the aqueous extract of Hallea ledermannii can be used orally up to the $5000 \mathrm{mg} / \mathrm{kg}$ dose without risk of toxicity and has chronotropic negative and hypotensive effects that could explain its use in traditional Gabonese medicine against high blood pressure.
\end{abstract}

Copy Right, IJAR, 2017,. All rights reserved.

\section{Introduction:-}

"Soft" medicine know considerable success in many parts of Africa. Surveys reveal that 80 to $85 \%$ of developing countries use medicinal plants for public health care (Organisation Mondiale de la Santé, 2002). The recourse of medicinal plants know up to this day a craze that could be explained by several reasons: The return to supposed natural products without adverse effects unlike conventional medicines; difficulties in accessing pharmaceuticals and their increasing costs; the importance given to medicinal plants by the pharmaceutical industry. Despite the place of antihypertensive drug products on the market, high blood pressure constitute up to this day public health problem whole world and in particular in developing countries. Today, high blood pressure has become a major

Corresponding Author:- Mba Akue Rony.

Address:-Laboratory of Naturel Substances and Organometallic Synthesis, University of Sciences and 1055 Technology of Masuku, BP 943, Franceville-Gabon and Chemistry Unit of Plant and Life, Faculty of Science and Technology, University Marien Ngouabi, BP 69, Brazzaville-Congo. 
cardiovascular risk factor representing a public health problem for African populations. In Gabon, the prevalence is about 25 to $30 \%$ (Kearney et al., 2004). The Gabonese flora it is full still several species of plants little or not studied, but endowed with true pharmacological properties, it is the case of Hallea ledermannii still called Mitragyna ciliata. This medicinal plant belongs to the family Rubiaceae. It is very present in marshy areas. It is rich in alkaloids (Burkill, 1997). Hallea ledermannii is a large tree can reach 20 to 35 meters tall with a diameter rarely reaching 0.8 to 1 meter, cylindrical, and without thickening at the base. Gabonese population uses this plant in the treatment of female infertility, for douching as a local antiseptic and bark decoction in association with other plant species is administered as an enema in painful menstruation (Raponda-Walker et Sillans, 1961; Gassita et al., 1982; Wagner, 1986).

\section{Material and Methods:-}

\section{Plant material:-}

The trunk bark of Hallea ledermannii were harvested in Franceville, in the Province of Haut-Ogooué (South-Eastern of Gabon) in March 2014. Identification of the species was carried out at the Institute of Research in Tropical Ecology and deposited at the National Herbarium of National Center of Scientific and Technical Research (CENAREST) of Libreville (Gabon). The bark was dried at Laboratory of Natural Substances and Organometallic Synthesis (LASNSOM) at Department of Chemistry of the Faculty of Sciences of USTM (Franceville) protected from light and at ambient temperature $\left(27-29^{\circ} \mathrm{C}\right)$ during 5 weeks. The dry bark was crushed and preserved in bottles out of glass safe from the light and moisture for later analyses.

\section{Animal material:-}

The present study was carried out on male swiss albino mice aged 8 to 10 weeks and of weight including between 25 and $30 \mathrm{~g}$ and wistar albino rats from 12 to 14 weeks and of weight including between 250 and $350 \mathrm{~g}$.

\section{Alimentation and habitat of animals:-}

The animals were supplied by the pet shop of the Faculty of Health Sciences of the Marien Ngouabi University where they were raised under natural aeration and lighting conditions. They were fed by a standard alimentation in the form of croquettes and were drinking ad libitum with drinking water.

\section{Preparation of plant extract:-}

The total extracts were prepared from the dry powder of the plant material. $100 \mathrm{~g}$ of powder were set to macerate in $1 \mathrm{~L}$ of solvent, respectively ethanol, water ethanol (500/500, v/v) and water, with magnetic stirring for 48 hours. The macerate was then filtered and then the solvent was evaporated to dryness under reduced pressure at $75{ }^{\circ} \mathrm{C}$ at help BÜCHI R-210 rotary evaporator. The extracts were concentrated and then kept in glass bottle for analysis.

\section{Preparation of the aqueous extract:-}

The aqueous extract was prepared by decoction from the dry powder of the plant material. $100 \mathrm{~g}$ of plant material powder were immersed in $1000 \mathrm{~mL}$ of distilled water. The mixture was heated with a hot plate with magnetic stirring for 30 minutes. After cooling, the extract was filtered and then the solvent was evaporated to dryness under reduced pressure at $75^{\circ} \mathrm{C}$ at help BÜCHI R-210 rotary evaporator.

\section{Phytochemical screening:-}

The chemical characterization of the secondary metabolites contained in the plant extract was carried out according to the conventional methods described by Bouquet (1972). Thus, we carried out the tests of alkaloids (reactive of Dragendorff and Mayer), anthocyanins ( $\mathrm{HCl} 20 \%$ ), anthraquinons ( $\mathrm{KOH} 10 \%$ ), flavonoids (reaction to the cyanidin), triterpenoids (reaction of Liebermann-Bouchard), saponosids (foam index), gallic tannins and catechic tannins (ferric chloride, Stiany), reducing compounds (reagent of Fehling) and carotenoids.

\section{Phenolic content:-}

The total phenolic contents of the different extracts were determined by the method of Folin-Ciocalteu (Singleton et Rossi, 1965). A quantity of $200 \mu \mathrm{L}$ of the extract is mixed with $1 \mathrm{~mL}$ reagent of Folin-Ciocalteu coldly prepared (10 times diluted) and $0.8 \mathrm{~mL}$ sodium carbonate solution $(7.5 \%)$. The unit is incubated at ambient temperature during $30 \mathrm{~min}$ and the reading is carried out against a white using a spectrophotometer with $765 \mathrm{~nm}$. All analyses were done in triplicate and results (average of triplicate analysis) are expressed in milligrams equivalent of gallic acid per gram of dry vegetable matter. 


\section{Flavonoid content:-}

The content in flavonoids of the extracts was given by using the colorimetric method with aluminum chloride(Kim et $a l ., 2003)$. A quantity of $100 \mu \mathrm{L}$ of the extract was mixed with distilled water $0.4 \mathrm{~mL}$ and thereafter with $0.03 \mathrm{~mL}$ sodium nitrite solution ( $5 \%$ ). After $5 \mathrm{~min}, 0.02 \mathrm{~mL}$ aluminum chloridesolution $(10 \%)$ was added. One adds with the mixture $0.2 \mathrm{~mL}$ sodium carbonate solution $(1 \mathrm{M})$ and $0.25 \mathrm{~mL}$ distilled water after 5 min with rest. The unit is agitated using a vortex and the absorbance was measured to $510 \mathrm{~nm}$ was recorded after 30 min of incubation. A standard calibration plot was generated using known concentration of quercetin. The results are expressed in milligrams equivalent of quercetin per gram of dry vegetable matter.

\section{Acute toxicity:-}

After three days of acclimatization in the laboratory, the mice were fasted for 4 hours before administration of the products without removing them from the water. Acute oral toxicity was assessed in accordance to the OECD Guideline $n^{\circ} 423$ (2001). Five (5) batches of three (3) mice each were constituted and treated orally in the following manner: Control batches were treated at distilled water $(0.5 \mathrm{~mL} / 100 \mathrm{~g})$ and the other batches treated at aqueous extract of Hallea ledermannii at the respective doses of 50, 300, 2000 and $5000 \mathrm{mg} / \mathrm{kg}$. After administration of the products, each mouse was placed in an individual cage for 1/2, 1, 2, 3 and $4 \mathrm{~h}$ observations on spontaneous motricity, aggressiveness, responses to external stimuli, Stools, ptosis, piloerection, convulsions. Batch mortality was assessed within 48 hours of product administration. The body weight of each animal as well as food consumption were recorded every other day for 14 days (OECD, 2001).

\section{Evaluation of cardiovascular effects:-}

\section{Anesthesia of the animal and catheterization of the femoral vein and the carotid artery:-}

The general anesthesia of the rats was carried out by intra-peritoneal injection of urethane $15 \%$ at $1.5 \mathrm{~g} / \mathrm{kg}$ at the rate of $1 \mathrm{~mL} / 100 \mathrm{~g}$ of rat body weight (Dimo et al., 2003). The anesthetized animal was fixed in dorsal decubitus, by means of pins planted on these legs on a cork board. The femoral vein and then the carotid artery were exposed and then catheterized, respectively, using fine polyethylene catheters attached to a syringe and introcan $24 \mathrm{G}$ catheters as described by Etou Ossibi and al (2010). The $10 \%$ heparinized $\mathrm{NaCl}(0.9 \%)$ solution was injected at a rate of 0.1 $\mathrm{mL} / 100 \mathrm{~g}$ by the femoral vein to prevent blood coagulation. When the clamp is removed, the blood engulfs into the catheter Introcan $24 \mathrm{G}$ and transducer of type Biopac Student Lab MP 36 transmits the variations of the blood pressure at recorder of the same type that converts the waves into traces (records Blood pressure and heart rate) that can be viewed on the computer screen and whose values are read directly (Nguelefact, 2008).

\section{Administration of the aqueous extract of Hallea ledermannii:-}

After a period (about $30 \mathrm{~min}$ ) of blood pressure stabilization, a physiologic solution of $\mathrm{NaCl}(0.9 \%)$ and the aqueous Hallea ledermannii extract $(10,20$ and $30 \mathrm{mg} / \mathrm{kg})$ were administered to the normotensive rats $(\mathrm{n}=5)$ at a rate of 0.1 $\mathrm{mL} / 100 \mathrm{~g}$.After administration of the products, their effects on systolic blood pressure and heart rate were observed for 30 minutes.

\section{Statistical Analysis:-}

The results were analyzed at help of the Excel and expressed as mean \pm ESM. Analysis of variance (ANOVA) was done for batch comparison. The difference between the batches was significant at least at the $\mathrm{p}<0.05$ threshold.

\section{Results:-}

\section{Phytochemical screening:-}

The phytochemical screening was carried out from the total extracts to identify the main chemical groups present in the plant. Due to the results obtained, shown in table 1, it appears that the total extracts of Hallea ledermannii contain flavonoids, terpenoids, saponosides, cathechic and gallic tannins, anthraquinones, anthocyanins, alkaloids and reducing compounds. These plant extracts tested do not contain carotenoids.

\section{Totals phenolic and flavonoid Contents:-}

The results of the quantitative analysis of the total phenols and flavonoids are reported in table 2. The total phenol contents of the extracts are expressed in milligrams equivalent of gallic acid per gram of dry plant material (standard equation of the calibration curve: $\mathrm{Y}=0.0004 \mathrm{X}+0.0053, \mathrm{R} 2=0.9929)$ and those of total flavonoids are expressed in milligrams quercetin equivalent per gram of dry plant material (standard equation of the calibration curve: $\mathrm{Y}=$ $0.0005 \mathrm{X}+0.0044, \mathrm{R} 2=0.9963$ ). The polar extracts of Hallea ledermannii present low totals phenol and flavonoid 
contents. Water-ethanol extract has the highest total phenol content $(3.55675 \pm 0.083 \mathrm{mg} \mathrm{GAE} / \mathrm{g}$ of drug) and the total ethanolic extract in total flavonoids $(1.2272 \pm 0.197 \mathrm{mg} \mathrm{Q} \mathrm{E} / \mathrm{g}$ of drug).

\section{Acute toxicity:-}

The aqueous extract of Hallea ledermannii $(50,300,2000$ and $5000 \mathrm{mg} / \mathrm{kg}$ ) does not modify spontaneous motility, reactions to external stimuli, stool condition, nor does it provoke aggressiveness, ptosis, piloérection, convulsions of mice. No mortality of mice was noted at the doses studied. The LD50 is greater than $5000 \mathrm{mg} / \mathrm{kg}$. Regarding the weight evolution, the results obtained show that the mice which received the aqueous extract of Hallea ledermannii gain weight compared to the control mice (distilled water). The weight gain of the mice is greater with the dose of $300 \mathrm{mg} / \mathrm{kg}$ (figure 1). The results of figure 2 show that the food intake in the mice treated with the aqueous extract of Hallea ledermannii at the different doses studied is greater compared to that of the control mice having received distilled water at $0.5 \mathrm{~mL} / 100 \mathrm{~g}$.

\section{Effects of the aqueous extract of Hallea ledermannii on cardiovascular parameters:-}

Intravenous administration of the aqueous extract of Hallea ledermannii $(10,20$ and $30 \mathrm{mg} / \mathrm{kg})$ causes a significant immediate decrease in systolic blood pressure respectively of $12.83 \pm 1.33(\mathrm{p}<0.05) ; 21.86 \pm 1.86(\mathrm{p}<0.01)$ and $27.37 \pm 1.71 \%(\mathrm{p}<0.01)$ followed by rising and then permanently relapsing below the initial values from the 10th minute (figure 3). At these doses, significant decreases in heart rate are respectively $4.97 \pm 1.63$ (P> 0.05); $7.28 \pm$ 1.17 ( $\mathrm{p}<0.05)$ and $12.78 \pm 1.93 \%$ ( $\mathrm{p}<0.01)$. In rats treated with the $\mathrm{NaCl}(0.9 \%)$ physiological solution, immediate decreases in systolic blood pressure (SBP) and cardiac frequency (CF) are not observed (Figure 4).

Table 1:-Phytochemical screening of total extracts of Hallea ledermannii

\begin{tabular}{|c|c|}
\hline Chemical groups & Hallea ledermannii \\
\hline Alkaloids & ++ \\
\hline Anthocyanins & +++ \\
\hline Anthraquinones & +++ \\
\hline Flavonoids & ++ \\
\hline Terpenoids & +++ \\
\hline Saponosids & +++ \\
\hline Cathechics tannins & + \\
\hline Gallics tannins & ++ \\
\hline Reducing compounds & +++ \\
\hline Carotenoids & - \\
\hline
\end{tabular}

+++ = Very abundant; ++ = Abundant; + = not abundant; - = Not detected

Table 2:- Total phenolic content (TPC) and Total flavonoid content (TFC).

\begin{tabular}{|l|c|c|c|}
\hline Extracts & Yields (\%) & TPC (mg GAE/g of drug) & TFC (mg QE/g of drug) \\
\hline EE de Hallea $l$. & 6.545 & $2.78675 \pm 0,110$ & $1.2272 \pm 0,197$ \\
\hline EHE de Hallea $l$. & 13.245 & $3.55675 \pm 0,083$ & $0.7232 \pm 0,187$ \\
\hline EA de Hallea . & 7.172 & $3.27425 \pm 0,101$ & $0.8072 \pm 0,129$ \\
\hline
\end{tabular}

Hallea l. = Hallea ledermannii; EE = Ethanol extract; EHE = Water-ethanol extract;

$\mathrm{EA}=$ Aqueous extract; All measurements were reproduced three times. 


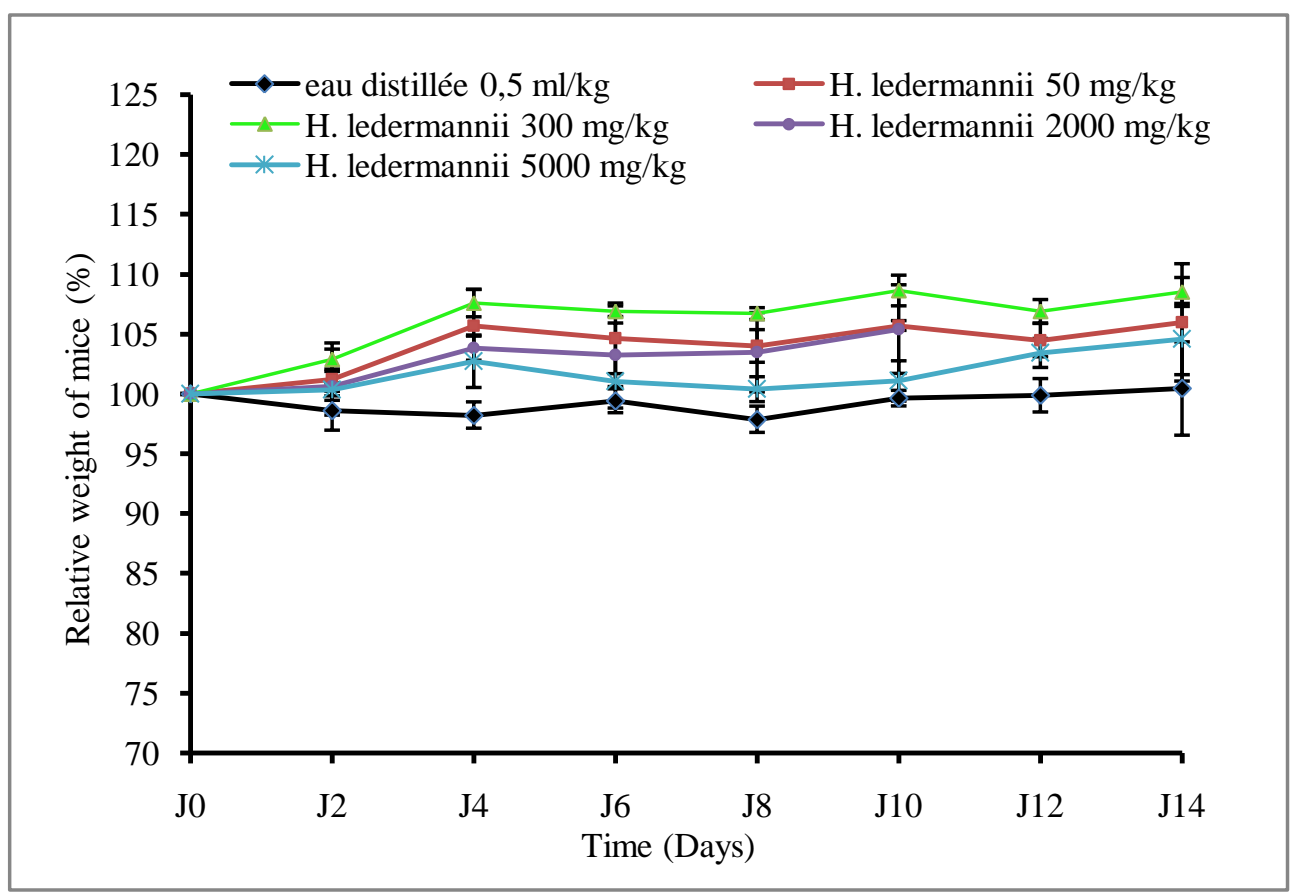

Figure 1:- Effects of the aqueous extract of Hallea ledermannii on the weight evolution of mice.Each point represents the mean \pm ESM, with $\mathrm{n}=3 . * \mathrm{p}<0.05, * * \mathrm{p}<0.01$ and $* * * \mathrm{p}<0.001$.

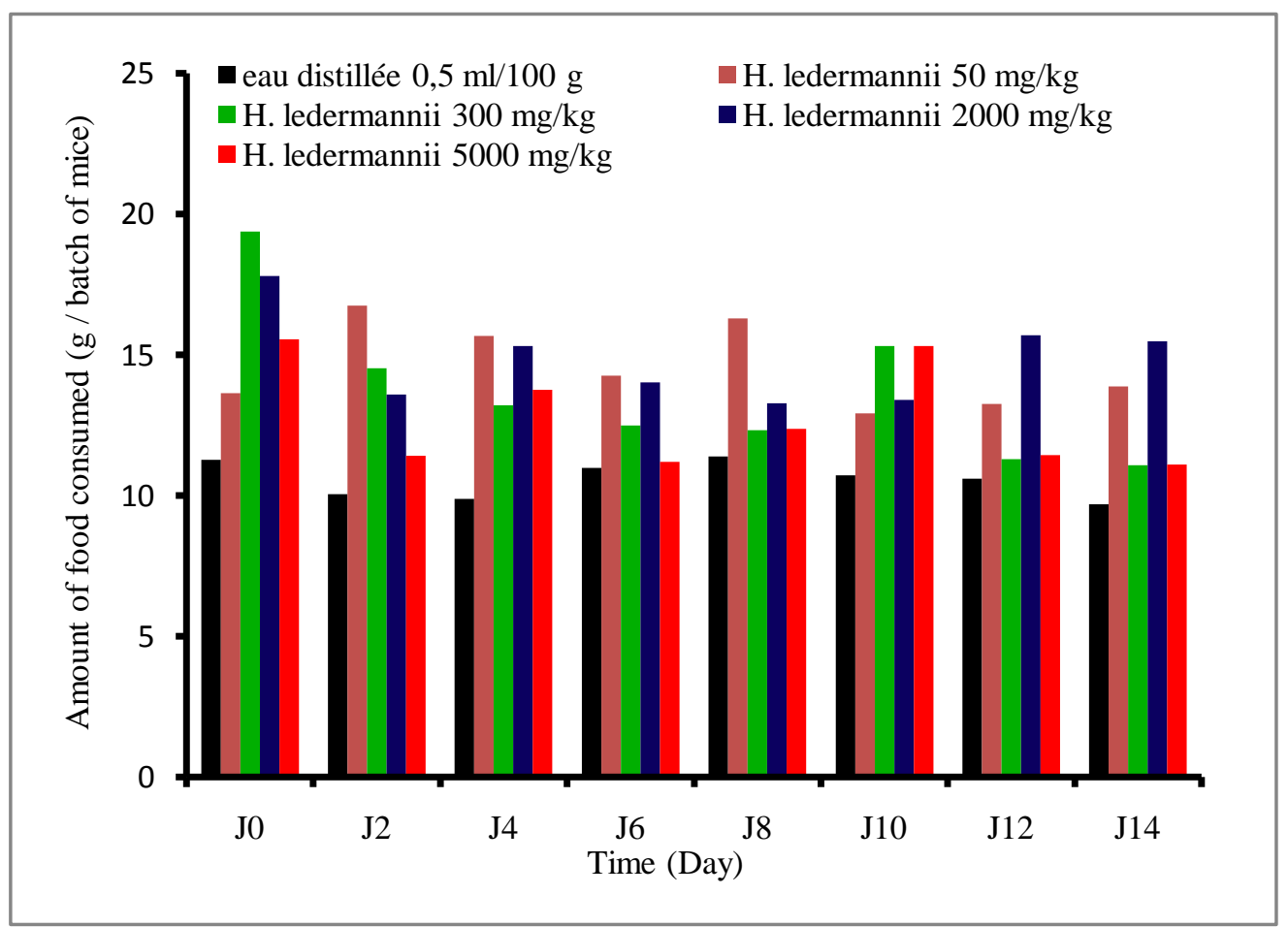

Figure 2:- Effects of aqueous extract of Hallea ledermannii on the feed intake of miceEach value is a mean \pm ESM, with $\mathrm{n}=3$. 


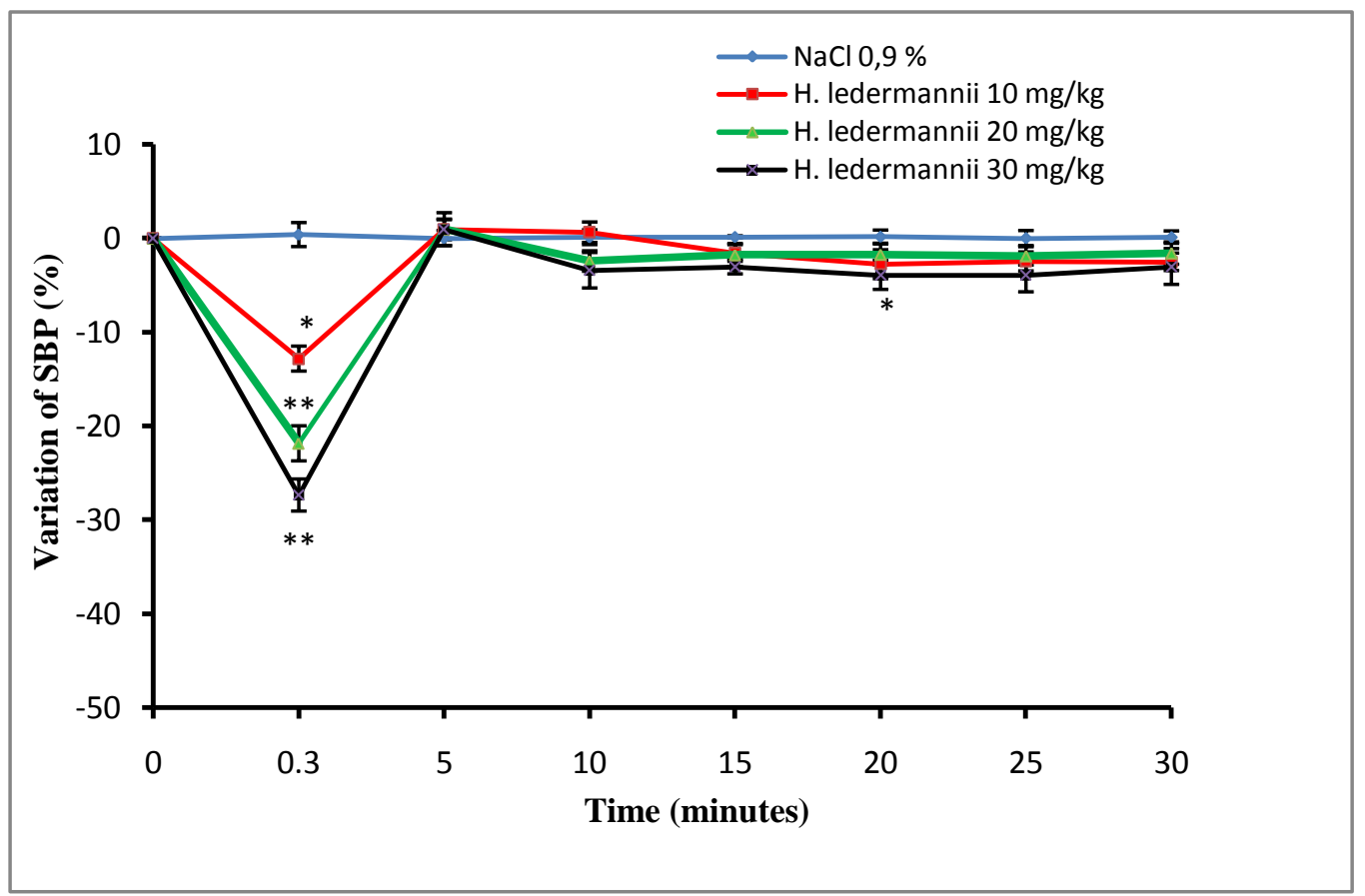

Figure 3:- Effects of the aqueous extract of Hallea ledermannii on systolic blood pressure in NTR. Each point represents the mean $\pm \mathrm{ESM}$, with $\mathrm{n}=5$. $* \mathrm{p}<0.05$ and $* * \mathrm{p}<0.001$ significant difference from the initial value.

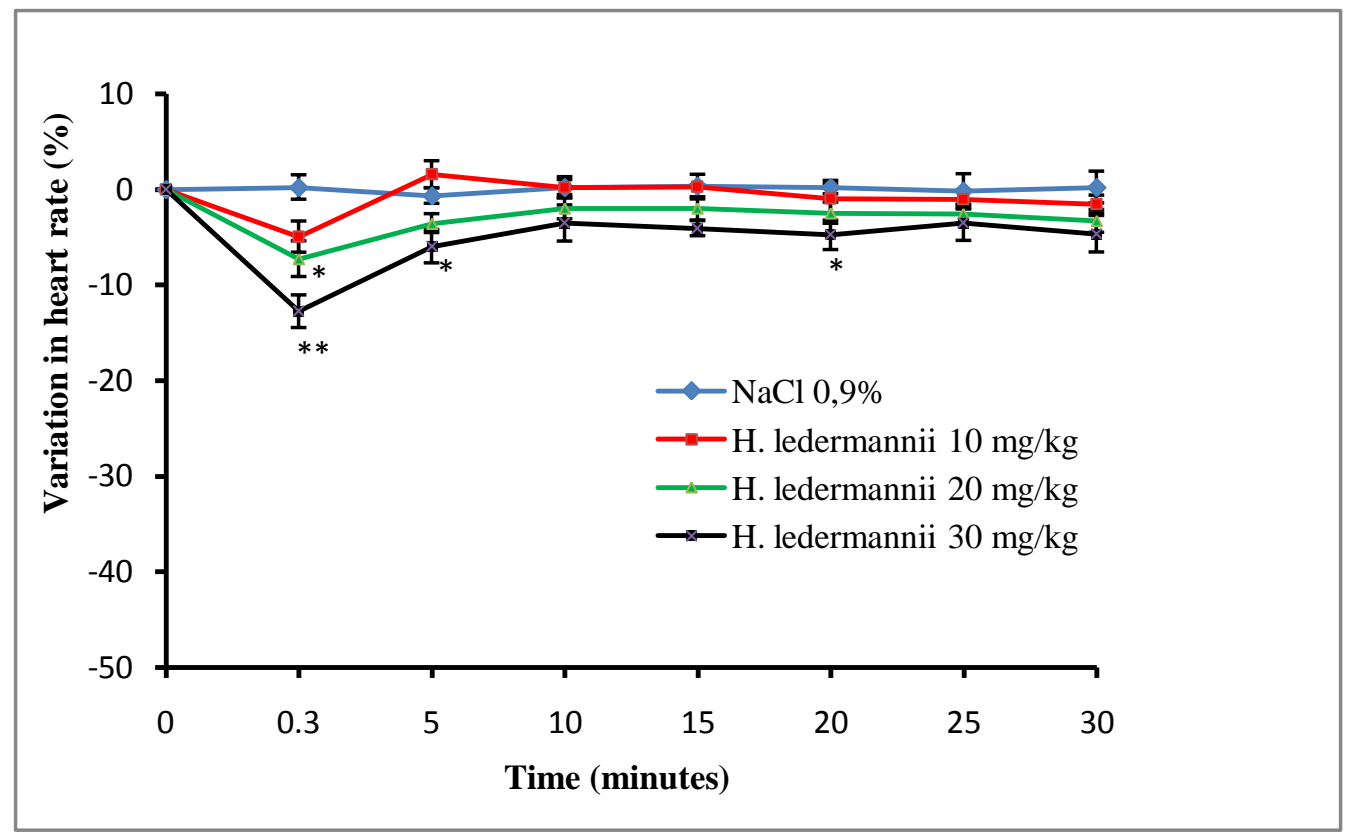

Figure 4:- Effects of Hallea ledermannii aqueous extract on heart rate in NTR. Each point represents the mean \pm $\mathrm{ESM}$, with $\mathrm{n}=5 . * \mathrm{p}<0.05$ and $* * \mathrm{p}<0.001$ significant difference from the initial value. 


\section{Discussion:- \\ Phytochemical Screening:-}

Eight chemical families have been identified: alkaloids, anthocyanins, anthraquinones, flavonoids, terpenoids, saponosides, tannins and reducing compounds. The test carried out on the carotenoids was negative. Hallea ledermannii is therefore a medicinal plant rich in secondary metabolites. These results are in agreement with those obtained by Mibindzou (2004) and Souleymane (2004) on the bark of Hallea ledermannii, harvested respectively in Libreville (in the South of Gabon) and in the Region of Abidjan (Côte d'Ivoire). On the other hand, BIDIE et al (2011) mentioned the total absence of gallic tannins in the methanol extract of the Hallea ledermannii bark harvested in the central western forest region in the Issia department of Côte d'Ivoire. This difference in chemical composition could be explained by the environment, geographical origin and harvest period, drying time, climate, parasites and extraction method (Svoboda and Hampson, 1999).

\section{Totals phenolic and flavonoid contents:-}

The results of the quantitative study show that the polar extracts of Hallea ledermannii have of the low contents of total phenols and total flavonoids. Water-ethanol and ethanol extracts have the highest contents respectively of total phenols and flavonoids. These results are different from those obtained by Adeleke et al (2012), on Hallea ledermannii leaves harvested in Nigeria, with a high total phenol content ( $88 \mathrm{mg} \mathrm{GAE} / \mathrm{g}$ of drug). This difference is probably due to various conditions especially plant maturity, environment, organ used, place of harvest, drying time, extraction method, climatic and environmental parameters (Svoboda And Hampson, 1999).

\section{Acute toxicity of aqueous extract of Hallea ledermannii:-}

The study of acute oral toxicity shows that the aqueous extract of Hallea ledermannii does not modify the behavior or the general state of the mice. Also, this extract does not cause the death of the mice up to the dose of $5000 \mathrm{mg} / \mathrm{kg}$. The aqueous extract of Hallea ledermannii is well tolerated and according to the System of Classification harmonized globally (GHS), the LD50 of this extract would be greater than $5000 \mathrm{mg} / \mathrm{kg}$ (OECD, 1998). Moreover, the results of the present study show that this extract causes an increase in the body weight of the mice and their feed intake compared to the controls (distilled water). The increase in food intake could be due to the stimulation of appetite by this extract. The weight gain of the mice which received the aqueous extract of Hallea ledermannii could be explained by their high food consumption.Indeed, it is reported that weight gain is proportional to food consumption (Guyton, 1989).

\section{Effects of the aqueous extract of Hallea ledermannii on cardiovascular parameters:-}

The aqueous extract of Hallea ledermannii causes immediate decreases in systolic blood pressure (SBP) and heart rate (HR) in normotensive rats. This extract therefore causes hypotension and a negative chronotropic effect. The negative chronotropic effect could in part explain the observed hypotensive effect of this extract. Indeed, it has been shown that the decrease in heart rate following the administration of plant extracts would be the cause of the drop in blood pressure (Etou Ossibi and al., 2010, 2014 and 2016). The rapid rise in systolic blood pressure could be explained by a reflex phenomenon consecutive the increase in the discharge of catecholamines (Guyton, 1989). Moreover, the presence of flavonoids, tannins and alkaloids in this plant could also explain the hypotensive activity of this extract (Souleymane, 2004; Bruneton, 1999). Previous studies have shown the vasculo-protective and vasodilating effects of polyphenols (flavonoids and tannins); effects involved in decrease blood pressure (Martin and Andriantsitohaina, 2002; Falleh and al., 2008; Xu and al., 2007).

\section{Conclusion:-}

Hallea ledermannii is a medicinal plant rich in secondary metabolites and well tolerated in mice with an LD50 greater than $5000 \mathrm{mg} / \mathrm{kg}$. It is therefore relatively non-toxic and therefore can constitute a good drug for pharmacological studies. The abundance of phenolic compounds this plant, reputed as vasodilators, could justify its use in traditional Gabonese medicine in the treatment of high blood pressure. These preliminary results could be very useful in the search for new active medications capable of effectively fighting cardiovascular diseases. Subsequent analyzes will enable to highlight the molecules responsible for this hypotensive activity and study their action mechanisms. 


\section{Remerciements:-}

We would like to express our sincere thanks to Mr. Michel LEMA, responsible of the Haut-Ogooué health tradipractitioners, and his team for advising us a medicinal plant commonly used in Haut-Ogooué to fight hypertension effectively.

\section{References:-}

1. Adeleke Adesegun., Anyika, N.E., OluseyiAdekoya, T. and Essien, S. G. (2012). Antibacterial and antioxidant investigations of Hallea ledermannii leaf extract. Indian Journal of Science and Technology.5 (1): 1885 -1887.

2. BIDIE, Alain dit Philippe., N'GUESSAN, Banga B., YAPO, Adou F., N'G UESSAN, Jean David. et DJAMAN, Allico Joseph. (2011): Activités antioxydantes de dix plantes médicinales de la Pharmacopée ivoirienne. Sciences \& Nature, Vol. $8 \mathrm{~N}^{\circ} 1$ : 1-11

3. Bouquet A. (1972): Plantes médicinales du Congo Brazzaville. O.R.S.T.O.M; Paris 13: p 8-13; 30.

4. Bruneton, J. (1999). Tannins. In: Pharmacognosie, phytochimie, Plantes médicinales, TEC\&DOC (Ed.), Paris, pp. 369-404.

5. Burkill, H.M. (1997): Useful plants of West Tropical Africa; Royal Botanic Gardens; Key; Vol.4; 970p.

6. Dimo T., Nguelefact T. B., Tan P. V., Yewah M. P. Dongo E., Rakotonirina S. V., Kamany A. I. and Bopelet M. (2003): Possible mecanisms of action of the neutral extract from Biden spilosa L. leaves on the cardiovascular system of anaesthetized rats. Pyrother Research., 17: 1135-1139.

7. EtouOssibi A.W. (2010): Effets cardiovasculaires et antioxydants des extraits aqueux et hydroéthanolique de LippiamultifloraMoldenke (verbenaceae). Thèse de Doctorat unique, Université Marien Ngouabi, République du Congo; $198 \mathrm{p}$.

8. EtouOssibi A.W., Elion Itou R.D.G.,Nzonzi J., et al., (2014): Effets de l'extrait aqueux de LippiamultifloraMoldenke(Verbenaceae) sur la pression artérielle, la fréquence cardiaque et les ondes de l'électrocardiogramme chez le rat normotendu. Revue CAMES-Série Pharm. Méd. Trad. Afr. 17(1): 1-9.

9. Etou Ossibi A.W., Elion Itou R.D.G., Nkounkou Loupangou C., HibandzaNyamibara J.D., BonazabaMilandou L.J.C., Ouamba J.M., Abena A.A. (2016): Effets des extraits polaires des feuilles de Tremaorientalis (Linn.) Blume (Ulmaceae) sur la pression artérielle moyenne chez le rat; 18(1): 8-15

10. Falleh, H.,Ksouri, R., Chaieb, K., Karray-Bouraoui, N., Trabelsi, N., Boulaaba, M., Abdelly, C. (2008): Phenolic composition of Cynaracardunculus L. organs, and their biological C. R. Biologies; 331: 372-379.

11. Gassita J.N., NzeEkekang Lucienne., De Vichy Hélène., Mels Louis Adrian., Koudogbo Blaise., Ekomie Richard. (1982): Les Plantes Médicinales du Gabon; Mission Ethnobotanique de l’ACCT au Gabon; Libreville; $55 \mathrm{p}$.

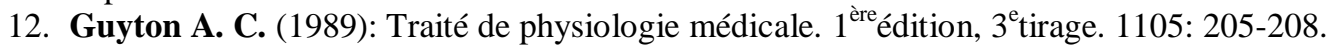

13. Karou, D.,Savadogo, A., Canini, A., Yameogo, S., Montesano, C., Simpore, J., Colizzi, V. and Traore, A.S. (2005): Antibacterial activity of alkaloids from Sidaacuta. Afr. J. of Biotechnol., 4:1452-1457.

14. Kearney PM, Whelton M, Reynolds K, Whelton PK, He J. (2004): Worldwide prevalence of hypertension: a systematic review. J Hypertens. 22(1):21-4.

15. Kim, D.O., Chun, O.K., Kim, Y.J., Moon, H.Y. et Lee, C.Y. (2003): Quantification of polyphenols and their antioxidant capacity in fresh plums. Journal of Agriculture and Food Chemistry, 51(22): 65096515.

16. Martin, S. etAndriantsitohaina, R. (2002): Mécanismes de la protection cardiaque et vasculaire des polyphénols au niveau de l'endothélium. Annales de cardiologieetd'angéiologie; 51:304-315.

17. Mibindzou Mouellet, A. (2004): Screening phytochimique des deux espèces de plantes: Crotaliaretusa L. (Papilionaceae) et Hallea ciliata Aubrev et Pellegr (Rubiaceae) récoltées au Gabon. Thèse de Doctorat, Université de Bamako, p.88

18. Nguelefact T. B. (2008): Effets analgésiques et cardiovasculaires des extraits de feuilles de Kalanchoecreneta (Andrews) Hawort. Thèse de Doctorat PhD, Université de Yaoundé I - Cameroun, p.162.

19. OECD. (2001): Ligne directive de l'OECD pour les essais de produits chimiques: toxicité orale aigue-méthode par classe de toxicité aigüe; $\mathrm{N}^{\circ} 423$, p. 14

20. OECD. (1998): Harmonized Integrated Hazard Classification System for Human Health and Environmental Effects of Chemical Substances as endorsed by the 28th Joint Meeting of the Chemicals Committee and the Working Party on Chemicals in November 1998, Part 2, p.11.

21. Organisation Mondiale de la Santé. (2002): Stratégie de l'OMS pour la Médecine Traditionnelle; Organisation Mondiale de la Santé ; Genève; 65p.

22. Raponda-Walker, A. et Sillans, R. (1961): Les Plantes Utilisées au Gabon; Paul Lechevalier; Paris, 616p. 
23. Singleton, V.L.et Rossi, J.A. (1965): Colorimetry of total phenolics with phosphomolybdic-phosphotungstic acid reagents. American Journal of technology and Viticulture, 16: 144-153.

24. Sivananthan, M. and Elamaran, M. (2013): In vitro evaluation of antibacterial activity of chloroform extract Andrographispaniculata leaves and roots, Duriozibethinus wood bark and Psidium guajava leaves against selected bacterial strains., 3: 12-19.

25. Souleymane F. (2004): Exploration Biochimique sur le Pouvoir Immunogène de trois Plantes en Côte d'Ivoire: Alstonia boonei (Apocynaceae), Mitragyna Ciliata (Rubiaceae) et Terminalia catappa (Combretaceae). Thèse de Doctorat, Université de Bamako., p.123.

26. Svoboda, K.P\&. Hampson, J.B. (1999): Bioactivity of essential oil of selected temperate aromatic plants: antibacterial, antioxidant, anti-inflammatory and other related pharmacological activities. Ed: Plant Biology Department, SAC Auchincruive, Ayr, Scotland, Uk., KA6 5HW.

27. Vyas, N., Tailan, M.,Gavatia, N.P. et Gupta, B.K. (2010): Antioxidant potential of Psidium guajava Linn. Int. J. of Pharm. Tech. Res., 2: 417-419.

28. Wagner Alain. (1986): Aspects des Médecines Traditionnelles du Gabon; Editions universelles; Toulouse., $332 \mathrm{p}$.

29. Xu, Y.C., Leung, S.W.S., Yeung, D.K.Y., Hu, L.H., Chen, G.H., Che, C.M., Man, R.Y.K. (2007): Structureactivity relationships of flavonoids for vascular relaxation in porcine coronary artery. Phytochemistry., 68: 1179-1188. 